\title{
Klasická sociologie Inocence A. Bláhy v kontextu soudobých diskusí ${ }^{*}$
}

\author{
DUŠAN JANÁK**
}

\section{Classical Sociology of Inocenc A. Bláha in the Context of Contemporary Discussions}

\begin{abstract}
The following text deals with the sociology of I. A. Bláha in the context of two contemporary discussions about values in social science: the first is a dispute about so called public sociology and the second represents feministic epistemological thinking. The author concludes we should distinguish between "public" and "engaged" sociology as two different ways of sociological entering to the public sphere. The public sociology is a wider concept which indicates the sociological entering to the public sphere and it doesn't content evaluative approach necessary. The engaged sociology is dealing with something or someone and the evaluation of reality is its attribute. A confrontation of Bláha's arguments with feminist epistemologies shows that the engaged social science impeaches the sharp barrier between facts and values and tries to interconnect factual and value judgments. From this point of view an evaluation bias a cognition and the cognition bias the evaluation. Although the interconnection of the evaluation and the cognition weaken the idea of infallibility or impartiality of scientific knowledge, on the other hand it weakens also the idea that, while delivering evaluative statements, we move in the sphere of absolute arbitrariness and irrational intuition and it boosts the idea that value biased discourse is possible as rational.
\end{abstract}

Keywords: Inocenc A. Bláha, Czech sociology, epistemology, public sociology, feminist social science

Znalost dějin klasických sociologických teorií tvoří standardní součást výuky oboru sociologie. Sdílení určitých konceptů, které jsou označovány za klasické je součástí sociologické socializace a usnadňuje (mimo jiné) komunikaci ve vědecké komunitě. Klasické sociologické teorie tak fungují jako jakýsi tmel, pomáhající udržet integritu oboru. Přitom soubor klasiků není nikterak pevně uzavřen. U některých z nich (např. Weber, Durkheim, Simmel, Marx) to vypadá, že mají svoji pozici zajištěnou navěky. Př́íklady jiných však ukazují, že k bytí sociologickým klasikem, je nezbytné a klíčové uznání ostatních sociologů, které může být nestálé. Klasik existuje pouze v procesech uznání jeho klasičnosti. Proto můžeme mluvit o zapomenutých, opomíjených či znovuobjevených klasicích v různých oblastech života, nejen v sociologii.

Jinou z důležitých a dost možná nejdůležitější vlastností sociologického klasika, je možnost aktualizace jeho díla. Klasikové jsou klasiky mj. proto, že jejich koncepce lze využít při řešení aktuálních problémů. Nebo proto, že problémy, které otevřeli stále přitahují pozornost jejich následníků. $V$ předkládaném textu bych chtěl z tohoto úhlu pohledu

* Předkládaný text je přepracovanou verzí některých částí mé disertační práce o Bláhově sociologii, kterou jsem obhájil na Fakultě sociálních studií v Brně v roce 2008. Dvěma anonymním recenzentům děkuji za doporučení k textu i upozornění na doplňující literaturu.

** PhDr. Dušan Janák Ph.D., Ústav veřejné správy a regionální politiky, Fakulta veřejných politik, Slezská univerzita v Opavě, Hradecká 17, 74601 Opava. E-mail: stoupax@centrum.cz 
připomenout jednoho z opomíjených klasiků české sociologie - Inocence Arnošta Bláhu (1879-1960). Jeho dvě výročí, která léta 2009 a 2010 přinášejí, nám poskytují jubilejní př́ležitost k průzkumu možností navázání na jeho dílo.

\section{Co je z Bláhy stále živého?}

Vztah k naší vlastní sociologické tradici formovaly na první pohled mimovědecké historické okolnosti. Poměrně slibně nastartovaný rozvoj české meziválečné sociologie přibrzdila válka a definitivně zmrazil politický režim v padesátých letech. Opětovné budování sociologie v šedesátých letech, zpomalené zase normalizací let sedmdesátých, a opakovaný boom sociálních věd, včetně sociologie, po další politické změně v roce 1989 jsou okolnosti, které neustále narušovaly kontinuitu české sociologické tradice a umožnily na její klasiky úspěšně zapomenout nebo je neutrálně opomíjet. Proto otázka: „Co je z Bláhy stále živého?“, kterou formuloval Jiří Sedlák [2000] na přelomu tisíciletí, nabývá spíše podobu tázání, co je možné z Bláhy oživit.

Z Bláhových konkrétních empirických výzkumů je dnes většina již sociologickým archaismem, přesto $v$ nich lze nalézt nosné koncepty. Jedním z nich je Bláhovo budování sociální typologie. Aktuálnost tohoto záměru dosvědčují shodné snahy v sociologii postmodernity Zygmunta Baumana [2002]. Baumanova typologie městských osobnostních vzorců (zevloun, turista, tulák, hráč) jistě nepostrádá sociologickou imaginaci a filosofickou hloubku, Bláhovou předností je zakotvení v empirii. Bláhovy sociální typy (sedlák, dělník, inteligent) nejsou abstrakce, ale osobnostní vzorce vymezené objektivními sociálními charakteristikami, zejména povoláním. ${ }^{1} \mathrm{~V}$ návaznosti na Bláhu se lze ptát, zda existují nějaké sociální typy charakteristické pro dnešní svět práce. Známý, i když v pưvodní formulaci [Reich 2002] poněkud vágní z hlediska potřeb empirického výzkumu, je koncept symbolického analytika. Je snad prototypem světa práce pozdně moderní doby? Má svůj typový protipól např́klad v lokálně vázaném nezaměstnaném?

Tyto a další otázky, které vzbuzují Bláhovy empiricky orientované sociologické výzkumy, můžeme ponechat pro tuto chvíli stranou. Díla klasiků mají obvykle větší platnost $\mathrm{v}$ obecnější rovině analýzy. $\mathrm{V}$ případě Bláhově stojí za zamyšlení angažovanost jeho sociologie, která je pro něj charakteristická. Bláhova sociologie jednoznačně směřovala k praktickým cílům a jeho texty často přecházejí od nehodnotící analýzy k sociální kritice a moralismu (charakteristickém např. i pro Masaryka). Bláha sám založil politickou stranu a (neúspěšně) kandidoval do Národního shromáždění a „jeho“ Vysoká škola sociální v Brně byla v roce 1947 koncipovaná s úmyslem vzdělávat praktické sociology a sociální pracovníky.

Přehlédneme-li z tohoto úhlu pohledu dějiny sociologie uvidíme, že otázka sociální angažovanosti sociálních věd a problém hodnotících soudů ve vědeckých textech se vytrvale objevuje v sociologii od doby jejího vzniku až do současnosti. Jako projekt prakticky orientované sociální vědy byla sociologie pojmenována Augustem Comtem. Zřetelně praktickou ambici prozrazují práce sociologického objektivisty Émila Durkheima.

1 Bláhovy výzkumy inteligence [Bláha 1937] či dělnictva [Bláha 1925] jsou analýzy životního stylu, opírající se jak o kvantitativní údaje (statistiky, měření prostoru bytů, zjištování výše a struktury výdajů domácností apod.), tak o kvalitativní charakteristiky (způsob oblékání, mluvy, trávení volného času apod.). K tomu je sice přidáno dost moralismu a sociální kritiky, nicméně realistické a empirické jádro těmto studiím nelze upř́ít. 
V protikladu k projektu nehodnotící sociologie Maxe Webera, behavioristické sociologie a naturalistickým snahám kultivovaným v linii kvantitativního empirického výzkumu od dob Otty Neuratha a Paula F. Lazarsfelda se objevují neméně časté úvahy, navazující na tvrzení Wilhelma Diltheye, že sociolog je součástí zkoumané sociální skutečnosti, které rozumí vždy také díky hodnotícímu vztahu k ní. Humanistická perspektiva Petera Bergera, „angažované pozorování“ Raymonda Arona, kritická sociologie Millsova nebo postmoderní (po)osvícenství Foucaultovo či explicitní vazba na projekt osvícenství v př́padě Habermasově jsou př́klady vyrovnání se s hodnotícím rozměrem sociologie ve 2 . polovině minulého století.

\section{Bláhova angažovaná sociologie v kontextu dvou soudobých diskusí}

V době nedávné a současné můžeme zaznamenat dvě významná ohniska diskusí o sociologické angažovanosti. První z nich představuje debata o tzv. veřejné sociologii (public sociology), kterou rozpoutal v roce 2004 tehdejší prezident Americké sociologické asociace Michaela Burawoy. ${ }^{2}$ Druhým jsou epistemologické diskuse probíhající ve feministicky orientované sociální vědě. Zatímco debata o veřejné sociologii se točí kolem problematiky úlohy sociologie ve společnosti, v epistemologických úvahách feministek a př́ležitostně i feministů jde o výzkum možností hodnotově zatíženého vědeckého poznání. Jinými slovy rozprava o veřejné sociologii se týká především cílů veřejně angažované sociologie, feministická epistemologie se vztahuje k metodologickým předpokladům takovéto sociologie. Mimo tato dvě ohniska existuje samozřejmě řada dalších zdrojů debat o sociologické angažovanosti s přesahy do politického diskurzu či jiných vědních disciplín. Pro účely předkládané jubilejní stati je však zúžení pohledu na uvedené dva kontexty ospravedlnitelné.

Hlavním Burawoyovým argumentem je tvrzení, že tradiční členění podle dichotomií kvantitativní/kvalitativní, teoretické/empirické nebo funkcionalismus/konfliktualismus není z pohledu soudobých konfliktů a napětí uvnitř disciplíny relevantní. Konfliktní linie vznikají spíše podél hranic čtyř typů sociologické práce, které jsou definovány roz-

2 V reakci na příspěvek Michael Burawoye [2005a], obhajujícího možnosti veřejné sociologie, se na stránkách nejrůznějších sociologických žurnálů rozvinula diskuse o úkolech sociologie ve veřejném životě. První větší debaty o veřejné sociologii proběhly na americkém kontinentě, např. v čísle 4 Social Forces z roku 2004 s ohlasy i v následujícím roce [např. Light 2005], nebo v 5 čísle periodika Social Problems z roku 2004, kde bylo publikováno šest autobiografických př́padových studií o praktikování veřejné sociologie s Burawoyovým komentářem [Burawoy at al. 2004]. Internetová encyklopedie Wikipedia uvádí tři sborníky k problematice veřejné sociologie vesměs amerických autorů, jistě existuje i bezpočet dalších reflexí a komentářu. Nicméně tím, že rozsáhlá diskuse o veřejné sociologii proběhla na stránkách dvou čísel Britského sociologického časopisu v roce 2005 s př́spěvky z různých koutů světa a měla předehru v podobě menší debaty britských sociologů o roli sociologie ve veřejném a politickém životě v témže časopise. Je zřejmé, že vůle k diskusi o veřejné roli sociologie je i mimo Spojené státy. V reakci na Burawoye zazněly hlasy z rozličných koutů sociologického světa, z Německa, Austrálie, z různých míst v USA (New York, Chicago, San Francisco, Washington), z Norska, Kanady, Velké Británie a asijského Singapuru. Konečně, abychom nemarginalizovali naši domácí sociologii, můžeme zmínit, že k problematice role sociologie ve veřejném životě směřovaly i některé př́ispěvky Petra Mareše, Zuzany Kusé a Dušana Janáka [srv. Kusá 2006] v úvodním bloku konference „Čím žije česká sociologie?“, konané v Brně v lednu 2006. Reflexi Burawoyova konceptu i diskuse o něm věnoval pozornost Jan Balon [nejobsáhleji Balon 2005]. Sám Burawoy se zasloužil o institucionalizaci veřejné sociologie, objevil se specializovaný časopis, internetové fórum, byly pořádány kurzy, konference a množství seminářů, včetně velké konference u př́ležitostí 99. výročí Americké sociologické asociace v roce 2004. 
ličným cílem i publikem, a tím i odlišnými normami vědecké práce. Tzv. profesionální sociologie uspokojuje profesní zájem a je určena pro kolegy. Cílem zakázkové sociologie určené klientům je praktická intervence. Kritičtí intelektuálové jsou obecenstvem pro kritickou sociologii, jejímž cílem je debata o základech vědění. Konečně veřejná sociologie je směřována $\mathrm{k}$ různým typům veřejnosti s cílem podpory veřejného dialogu [srv. Burawoy 2005a; Burawoy 2005b].

Burwoyova obhajoba veřejné sociologie a apelování na spolupráci rozdílných typů sociologické produkce vyvolala celosvětovou sociologickou diskusi, jejíž ohlasy lze zaznamenat dodnes (viz pozn. č. 2). Stejně jako v minulosti, také v otázce přijetí Burawoyova projektu se sociologové rozdělili na dva tábory. Ve většině př́íspěvků zmiňovaných v tomto textu se až na několik výjimek [např. Hall 2005] proti myšlence sociologie cíleně promlouvající o „věcech veřejných“ k neodborné veřejnosti žádný ze sociologů v zásadě nevyslovil. Spíše se zabývaly technickými obtížemi „jak na to“. Oproti tomu Jan Balon upozornil i na druhou stranu debaty, která Burawoyův projekt odmítla [Balon 2009: 1067-1068]. Podle něj Burawoyovu projektu „se sice dostalo široké pozornosti, nicméně celý jeho návrh byl v následujících dvou letech značně kritizován a v podstatě od základu dekomponován“ [Balon 2009: 1067].

Pro naše ohlédnutí za Bláhovou sociologií z debaty o veřejné sociologii vyplývají minimálně dva poznatky. Prvním je skutečnost, že od dob Bláhových veřejně působící sociologie i ambice (části) sociologie vstupovat do veřejného prostoru mimo hranice vědy stále existují. Druhým poznatkem, patrným z plejády příspěvků odrážejících různé zkušeností s veřejnou sociologií a názorů na ni, je, že existují různé způsoby vstupu sociologie do veřejného prostoru. Bláhův způsob byl jednoznačně normativní. At̃ už čteme Bláhovy drobnější práce určené spiše širší veřejnosti, např. Od osvobození mravního k osvobození politickému [1919], Mravní výchova se stanoviska sociologického [1921a], K psychologii doby [1922b], Zásady pokrokové politiky [1926], O laický základ mravní výchovy (1929), Masaryk a věda (1930), Kultura a politika [1946], Jak se dívat sociologicky na život [1947a], Dnešní krizi rodinného života [1947b] atd. nebo jeho práce bližší Burawoyově představě profesionální sociologie jako např. Město [1914], Filosofie mravnosti [1922a], Sociologie sedláka a dělníka [1925] či Bláhův opus magnum Sociologie inteligence [1937], ve všech nalezneme ve větší či menší míře zastoupenou hodnotící analýzu toho, co ve společnosti „funguje“ nebo „nefunguje“, včetně více či méně konkrétních návrhů na terapii.

Na opačné straně spektra leží zkušenosti sociologů, jejichž sociologické poznání bylo převzato veřejností bez jejich záměrného přičinění. $Z$ debaty o veřejné sociologii je však patrné, že často mohou zažít zklamání z dezinterpretace svých poznatků [srv. např. Beck 2005 nebo Ericson 2005]. Zajímavým příspěvkem je zkušenost Diane Vaughan, jejíž etnografický výzkum se dostal do veřejného oběhu bez ztráty sociologičnosti i informační hodnoty. Naopak masmédia a veřejnost přejala její slovník. Jednalo se o etnografický výzkum řetězu sociálních interakcí pracovníků Národní agentury pro letectví a kosmonautiku (NASA) a její organizační struktury, které předcházely katastrofě Challengeru. Autorka došla ve své monografii The Challenger Launch Decision [Vaughan 1996] k závěru, že je pravděpodobné, že se podobné případy budou opakovat. Její předpověd’ se potvrdila, když došlo k havárii raketoplánu Columbia v roce 2003. Vaughan byla katapultována do centra pozornosti veřejnosti a masmédií a v závěru se 
její veřejná sociologie přeměnila v zakázkovou, když ji NASA, respektive komise pro vyšetřování nehody Columbie, oslovila pro konzultace a pomoc v reorganizaci sociálních struktur umožňujících katastrofické scénáře [srv. Burawoy 2005b: 422]. Vaughan ovšem konstatuje výjimečnost toho, že její informace nebyly „přeloženy“ do triviálních frází. K úspěšnému veřejnému po̊sobení její sociologie přispěla skutečnost, že etnografický výzkum a vyčerpávající „hustý popis“ je přístupný i laickému vědění. K úspěchu veřejného působení sociologie, která funguje (nyní) spíše neviditelně a neinstitucionalizovaně, by podle ní přispělo její systematické zviditelňování a odměňování [srv. Vaughan 2005].

Ukazuje se, že normativní pozice není pro veřejnou sociologii nezbytností, i když k němu veřejná sociologie inklinuje. Normativismus veřejné sociologie není jednoznačně př́tomný nebo nepř́tomný, nutný nebo nepřípustný. Bláhova sociologie byla prakticky orientovaná s době odpovídajícím hodnotícím akcentem. Příklad analýzy organizační kultury NASA Diany Vaughan je však výmluvným dokladem toho, že do veřejného prostoru může úspěšně vstoupit i sociologie neangažovaná a nenormativní. Normativní implikace jsou v tomto př́ipadě výhradně záležitostí uživatelů.

Proto by bylo vhodné rozlišovat angažovanou a veřejnou sociologii jako dva ne zcela identické pojmy. Veřejná sociologie je pojmem širším, odkazujícím na vstup sociologie do veřejného prostoru mimo hranice vědy. Angažovaná sociologie je sociologiî angažovanou za něco nebo někoho, např. na marginalizované jednotlivce nebo národní zájmy apod. V př́ípadě Bláhovy sociologie není tak jednoduché určit, za co nebo koho se stavěla jeho sociologická angažovanost, zaštitující se vágním „sociálním celkem“, za nímž lze někdy tušit mikroorganismus rodiny (Sociologie dětství, Dnešní krize rodinného života), v jiných kontextech národní stát (Sociologie sedláka a dělníka), jindy je jím zase celé lidstvo (Filosofie mravnosti, Sociologie inteligence). Nicméně můžeme konstatovat, že nejen v Bláhově př́ípadě, ale i dnes veřejná i angažovaná sociologie v různých podobách existuje.

Projekt veřejné sociologie a jeho diskuse se týká především úkolů a cílů (respektive jednoho z úkolů a cílů) sociologického snažení. Je to debata o vyústění a zakončení sociologického zkoumání. Dříve nebo později nás otázky o cílech přivedou k otázkám o začátcích. Vyvstávají před námi otázky legitimity a zakotvení projektu, jeho možný počátek na elementární bázi epistemologického zkoumání možností angažovaného poznání. Standardní námitka badatelů pracujících s korespondenčním pojetím pravdy spočívá v tom, že aktivismus je legitimní, ale leží za hranicemi vědy. Věda zkoumá a v principu neutrální výsledky je možné užít podle hodnot uživatele rozličným způsobem. Vyvstává tedy otázka, o jaký typ vědy se jedná. Nebo není vhodné označovat angažovaný výzkum za vědu, ale za občanský aktivismus vědců?

V protikladu k takovému tvrzení se pokusím na př́kladu Bláhovy sociologie ukázat, že pro angažovaný výzkum bývají charakteristické určité ontologické a epistemologické závazky, které se odráží i v jeho charakteristické metodologii. Jinými slovy, některé výchozí teoretické postuláty a základní pojmy určité sociologické teorie uschopňují tuto teorii k hodnotícím soudům více než tomu může být u teorie jiné. Také Bláhova sociologická angažovanost nebyla (pouze) záležitostí jeho mimosociologické občanské iniciativy, ale vyplývala (do jisté míry) z jeho obecné sociologické teorie. 


\section{Atributy a akcidenty Bláhovy angažované sociologie}

Uvedenou souvislost je možné ukázat na třech př́íkladech: Bláhově užití pojmu funkce, jeho pojetí pravdy a empirické metody v sociologii. Srovnáme-li Bláhovo použití pojmu funkce s pojetím dalšího českého sociologického funkcionalisty Josefa L. Fischera [1933a; 1933b], popř́ípadě s funkcionalisty světovými, Durkheimem [1926; 2004], Parsonsem [1964], Luhmannem [2006], dojdeme velice rychle k závěru, že neexistuje jeden sociologický funkcionalismus, ale jeho více typů. Podle pojetí funkce a jejího zasazení do obecného ontologického modelu společnosti je možné Bláhovu konečnou formulaci označit za federativní funkcionalismus, protože zdůrazňuje ontologickou rovnocennost i proměnlivost jednotlivých funkcí. U Fischera je možno mluvit o funkcionalismu hierarchickém, Durkheimův a Parsonsův funkcionalismus (v období Sociálního systému) bychom mohli vzhledem k oběma předchozím ozdobit přívlastkem statický, nebot oba uvažují o funkcích coby procesech udržujících stabilitu společnosti. Luhmannovu koncepci lze označit za funkcionalismus systémový, protože pojem funkce používá na úrovni obecné analýzy systémů, jako základní nástroj artikulace „stavových problémů“ systémů. Své tvrzení bych se pokusil podpořit podrobnějším srovnáním.

Filosoficky možná ještě důkladněji než Bláha se problematikou funkcí (v sociologii, filosofii, politice) zabýval jeho brněnský kolega Josef L. Fischer. Své pojetí uceleně vyložil v úvodních a závěrečných pasážích Krize demokracie [Fischer 1933a; 1933b]. Pro Fischera - podobně jako pro Bláhu a Luhmanna - jsou sice funkce pojmové nástroje pro analýzu, jejich konstruovanost je však jen částečná (není libovưlí), nebơ konstrukce má oporu v realitě. Funkcionální vysvětlení je nejvhodnější k popisu „kvalitativního kosmu“, který by měl střídat mechanický svět „kvantitativního kosmu“ ovládaného „duchem tíže“, kterým rozumí jednostranně kvantifikující pohled na skutečnost, stírající kvalitativní rozdíly ve jsoucnu, nepřevoditelné na jediné měřítko. Skutečnost adekvátněji znázorňuje hierarchicky uspořádaný „kvalitativní kosmos“ - tj. představa emergentních a autonomních vrstev jsoucna. Nelze mezi nimi hledat kauzální vztah a vykládat vyšší vrstvy nižšími ani naopak nižší vyššími - jejich vznik představuje pro Fischera neřešitelnou otázku [Fischer 1933b: 17]. Kritériem hierarchie je stupeň svéprávnosti, provázený stoupající svobodou při současně rostoucí početnosti nových vazeb, takže vyšší vrstvy jsou sice svobodnější i diferencovanější, ale zároveň křehčí [Fischer 1933b: 21].

Fischer svůj ontologický model aplikuje především na společnost, kde nejnižší funkce jsou podle něj funkce hospodářské (zaměřené na záchovu) a nejvyšší naopak funkce kulturně tvořivé (zaměřené na svobodný rozvoj). Tvorba kulturní vyrůstá z prŕrodní základny jako „kvalitativně vyšší sféra skutečnosti“ [Fischer 1933b: 26]. „Skladebnou společností“ nazývá Fischer ideální společenské uspořádání, které respektuje ontologickou hierarchii jsoucna i společenských funkcí. Svéprávnost a autonomie funkcí končí tam, kde začíná doména funkcí jiných. Pro funkce je optimální stupňování svéprávnosti a jejich autonomní rozvoj po mez odpovídající jejímu kvalitativnímu pořadí [Fischer 1933b: 47]. Každá vykonávaná funkce má v ontologickém pořadí své místo a nesmí se plést do kompetencí jiných funkcí.

Na rozdíl od Fischerova hierarchického modelu společnosti dospívá Bláha v obecné sociologické teorii $\mathrm{k}$ formulaci tzv. federativního funkcionalismu, jehož obsahem je důraz na vzájemnost a rovnocennost jednotlivých funkcí. Zatímco Fischerovu skladebnou vizi si lze představit jako pyramidu, Bláhovu představu lze nahlížet spíše jako 
rhizom (všemi směry rozrostlou organickou sít bez jasného centra) vzájemných závislostí a vlivů, který jde naprríč celou jeho strukturou. Pojem funkce v pokročilých fázích své sociologie Bláha jasně spojuje se sociálními činnostmi. V Sociologii rozebírá společnost jako organizaci různých skupin, ${ }^{3}$ jejichž nejcharakterističtějším rysem je jejich funkce. Sociální funkcí skupiny rozumí Bláha „činnost té které sociální skupiny, zaměřenou na zachování její existence a na její přežití a zároveň i na službu širšímu celku. Čím se jedna skupina liší od skupin jiných, a ovšem i ode všeho, co není skupina, jest její funkce“ [Bláha 1968: 13]. Funkce je činnost, případně tvořivá činnost, jejímž cílem je uspokojování potřeb [Bláha 1968: 28]. Sociální funkce tedy odpovídá sociálním potřebám, o nefunkčnosti se uvažuje ve vztahu k těmto potřebám. ${ }^{4}$ Některé sociální funkce se podmiňují, jiné existují netečně vedle sebe.

Obecný mechanismus vzniku sociálních potřeb a odpovídajících funkcí modeluje Bláha pomocí pojmu „obecná sociální situace“. Jakmile dochází k agregaci a interakci lidí, vzniká zároveň „potřeba nějak se navzájem uspořádat, nějak se konstituovat v řád“ [Bláha 1968: 12] skrze interakce, které mají povahu psychického i činnostního vztahování $\mathrm{k}$ druhému, tedy působení na druhé a druhých na individuum. Výsledkem těchto interakčních procesů je nezáměrná změna partikulárních psychik, citů, názorů ve smyslu určité jednoty. Z perspektivy sociálního celku (skupiny) je sociální funkce řádovou činností odpovídající sociální potřebě, z pohledu individua je to jednání odpovídající nějaké normě.

Objektivní norma však nevznikne podle Bláhy nějakým stanovením, prosazením individuální vůle. Jedinec by sám nevymyslel uspokojivou normu [Bláha 1921b: 664]. Objektivní norma vzniká vyrovnáváním subjektivních norem (tj. subjektivních hodnot) členů společnosti či participujících na sociální situaci.

Klíčové pojmové body Bláhovy koncepce dynamiky sociálních funkcí lze shrnout do následujícího modelu. Sociální funkce jsou určité regulované sociální činnosti určované sociálními normami, jež vznikají objektivizací subjektivních hodnot a vytvářejí tlak na jednotlivce. K objektivizaci subjektivních hodnot dochází v tzv. sociální situaci, kdy ve vzájemném tlaku interakčních procesů, z obecné potřeby upravit mezilidské vztahy, dochází k pozměňování individuálních hodnot a vzniku objektivních sociálních hodnot. Protože hodnocení je především mimoracionální praktickou aktivitou, kterou nelze zcela přesně predikovat, a hodnoty jsou právě touto praktickou emoční a volní aktivitou vytvářeny a reprodukovány, může dojít k nepředvídatelné změně hodnot a tedy i norem a sociálních funkcí.

Od klasiků sociologického funkcionalismu Parsonse a Durkheima se Bláhův funkcionalismus odlišuje díky tomuto individuálnímu prvku, který „znáhodňuje“ průběh sociální situace. Jedna z důležitých námitek byla namířena proti funkcionalistickému předpokladu společenské stability jako základní tendence společnosti a pochopení této tendence jako konformity s celospolečenskými hodnotami, u Parsonse s hodnotami daného systému vyjádřenými zejména v rolových očekáváních, u Durkheima v pojetí individua jako pouhého nositele kolektivních představ. Zejména známá Giddensova kritika

3 „Jakmile je lidský plurál vázán vnitřně (sociálně psychicky) i vnějším jednáním, jde o sociální skupinu [Bláha 1968: 12].“

4 Například o „perverzi spolkové funkce“ Bláha uvažuje v tom případě, „když spolek neodpovídá žádné sociální potřebě“ [Bláha 1968: 386-387]. 
[Giddens 1994, 1. vydání 1976] odhaluje s tímto postulátem související přehlížení role aktéra v sociálním procesu, který je v optice funkcionalismu redukován na entitu internalizující společenské normy, dále ignorování ahistoričnosti funkcionalistické koncepce opomíjející okolnosti vývoje sociálních struktur a kladoucí přehnaný důraz na statiku a konečně pak pomíjení nerealistického pohledu na společnost jako harmonickou soustavu funkcí bez přihlédnutí k reálnému předivu mocenských vztahů.

Do značné míry je tato kritika oprávněná, minimálně v rozpoznání předpokladů, na kterých výstavba funkcionalistické teorie spočívá - tj. na předpokladu priority stabilizačních principů. To je patrné na př́kladu Parsonsovy sociologické teorie, snažící se sice potřeby systému popsat nehodnotícími pojmy čtyřdimenzionálního modelu na první pohled rovnocenných „funkcionálních imperativư “ schématu AGIL, ale je zřejmé, že nejvýznamnějším imperativem je „L“ značící udržování hodnotových vzorců, tedy funkce garantující udržování a přenos hodnot dané kultury (instituce náboženství, školy, rodiny). Ze stručného představení Bláhovy koncepce federativního funkcionalismu je patrné, že uvedená kritika v prvních dvou bodech na ní není použitelná a umožňuje nám v tomto kontextu označit Durkheimův a Parsonsův funkcionalismus predikátem statický.

I přes někdy značné odlišnosti různých variant sociologického funkcionalismu se nám však rýsují určité společné charakteristiky vázané k pojmu funkce. Sociologický pojem funkce v sobě obsahuje teleologické konotace. Funkce v systému vždy obsahuje určitý problémový horizont jako svůj korelát. To si koneckonců uvědomovali jak čeští, tak zahraniční autoři. ${ }^{5}$ Teleologický rozměr pojmu funkce však nemusí vést nutně k diskvalifikaci tohoto pojmu. ${ }^{6}$ Bláha, Fischer i Luhmann oceňují jeho heuristickou efektiv-

$5 \quad$ Z našich autorů se Parsonsovým funkcionalismem podrobně a zasvěceně zabývali Jaroslav Klofáč a Vojtěch Tlustý [1965] a jedna část jejich kritiky směřuje právě k teleologickým prvkům Parsonsovy koncepce. Jejich práce je cenná mj. proto, že mapuje i dobovou diskusi a kritiku Parsonsova funkcionalismu. Stručnou souhrnnou kritiku strukturního funkcionalismu parsonsovského typu podává také Jan Keller [1992: 93-94]. Samotný Durkheim se snažil výtkám z teleologie čelit systematicky už v klasickém díle, v Pravidlech sociologické metody [srv. Durkheim 1926: 122-144]. Robert K. Merton se pokoušel problém funkcionálního vysvětlování odstranit zavedením dichotomie pojmů „latentní“ a „manifestní funkce“ a cílem sociologické analýzy učinit prvně jmenované. Ovšem sám přiznává, že funkcionální analýza obsahuje určité pojetí „funkcionálních požadavků systému“, vztažení činností k „potřebám systému“ [Merton 1965: 52], takže ani analýza latentních funkcí principiální problém teleologičnos-ti funkcionálních vysvětlení definitivně neřeší. Také z Luhmannova textu vyplývá, že pojem funkce v sociologické analýze vždy obsahuje teleologické konotace, nese (v sociologii) vždy určitý problémový horizont, řešitelskou úlohu, kterou funkcionální vztah řeší. Nejzákladnější orientační bod funkcionální analýzy představuje „orientace na problém, který je na jedné straně imanentní jejímu předmětu, ale zároveň se do určité míry stává problémem díky analýze samotné“ [Luhmann 2006: 74]. Proto vlastní teoretická práce, připravující půdu pro použití funkcionálních analýz podle Luhmanna spočívá v konstrukci problémů. Klasická verze této souvislosti chápala nejzákladnější problém jako problém stavu nebo stability systému, což není v Luhmannově pohledu nesprávné, avšak je to nedostatečné [Luhmann 2006: 71]. Luhmann nabízí své pojmy: diference systém/prostředí, komplexita, sebereference a časové kombinace ireverzibility a reverzibility jako metodologicky použitelné artikulace „stavových problémů“ systému s cílem „odhalit lepší a hlavně komplexnější možnosti analýzy a srovnání“ [Luhmann 2006: 71].

6 Problém teleologie byl tématem živých diskusí v české meziválečné sociální vědě a v 30 . letech téměř brněnskou specialitou. K polemice mezioborového charakteru dal podle filosofů a historiků české filosofie [Zouhar - Pavlincová - Gabriel 2005: 139-149] podnět Karel Engliš svým spisem Teleologie jako forma vědeckého poznání [1930]. V něm shrnul své myšlenky inspirované novokantovsky orientovanou brněnskou normativní školou právní, konkrétně pracemi Františka Weyra. Z brněnských filosofů se do polemické názorové výměny pustil Josef Tvrdý, s nímž Bláha sdílel některé názory na problematiku hodnocení i na pozitivismus. 
nost, samozřejmě s přihlédnutím ke korelujícím reálným procesům. S takovýmto pojetím lze jistě souhlasit.

Z našeho pohledu je důležité, že teleologický rozměr funkcionálního vysvětlování obsahuje potenciál hodnotících soudů. Pojem funkce ovšem hodnotící soudy neimplikuje nutně, pouze je lépe umožňuje. Pojmy nejsou kameny s jasně vymezitelnými hranicemi a v případě nehodnotícího a hodnotícího použití pojmu funkce jde spíše o kontinuum mezi dvěma póly, než o dvě jasně oddělené možnosti. Zárodek hodnotícího použití není u Bláhy v samotném pojmu funkce, ale v ontologických východiscích jeho sociologické teorie, která vycházejí z Durkheimova pojetí společnosti jako bezrozporné jednoty. I přes uvedené rozdíly Bláhova na jedné a Parsonsova a Durkheimova funkcionalismu na druhé straně, lze i na Bláhovu koncepci použít třetí bod Giddensovy kritiky funkcionalismu, opomíjení faktoru moci. Již v základním modelu sociální situace se nepředpokládá možnost, že by nedošlo k vzájemnému přizpůsobení. Respektive tato možnost trvalého konfliktu je v Bláhových textech pojednána jen jako dočasná anomálie.

Další zdroj hodnotícího užití pojmu funkce spočívá zřejmě v reziduích Comtova pojetí pokroku promítajícího se v Bláhově zacházení s pojmy evoluce a sebezáchovy, které vyzdvihuje poslední evoluční stadia jako hodnotnější než stadia předchozí, a vývoj tak pojímá jako proces neustálého zlepšování. Poslední stadium kosmické evoluce - duchovní realita společnosti vzniklá interakcí - se stává měřítkem, a to, co její křehkou jednotu narušuje, lze označit za disfunkční. Odtud plynou Bláhovy poznámky o funkčnosti a nefunkčnosti určitých sociálních institucí. Ukazuje se, že konečné hodnotící použití pojmu funkce vyplývá mimo jiné ze spojení pojmu s dalšími stavebními kameny v zásadě nehodnotící (deskriptivní) obecné sociologické teorie, které však mohou v celku Bláhovy teorie „fungovat“ jako kritérium funkčnosti.

Dalším prvkem Bláhovy sociologické koncepce, který ji lépe uschopňuje pro veřejnou či angažovanou sociologii je jeho pojetí objektivní pravdy. Poměrně podrobnému rozboru tohoto aspektu Bláhovy sociologie byl věnován prostor na jiném místě [Janák 2006]. Zde stačí upozornit, že v průběhu svého vědeckého vývoje si Bláha postupně uvědomoval limity pojetí poznání jako totožnosti (plné korespondence) s objektem, ačkoli zároveň stále trval na pozitivních (tj. empirických) základech vědění. Výsledkem tohoto vývoje u něj bylo přesunutí důrazu ze substanciálních kritérií objektivity na kritéria procedurální. Objektivní je pro něj především nadindividuální, nikoli nezávislé na člověku jako takovém. Vědecká pravda je pro Bláhu objektivní především proto, že její objektivita spočívá v překračování parciálního postoje směrem k nadindividuálnímu. Objektivní pravda není vlastnost korespondence vět a na subjektu nezávislé reality, ale výsledek sociálního procesu - vědeckého dialogu. Poznatky nenabývají diskrétních hodnot objektivně pravdivý/objektivně nepravdivý, ale spíše dosahují rozdílného stupně objektivní pravdivosti. Plná korespondence je normativní ideál vědecké práce, nikoli reálná skutečnost.

K takovému pojetí objektivní pravdy se Bláha propracovával postupně v souvislosti se svým promýšlením adekvátní sociologické metody. V tomto kontextu zaslouží pozornost Bláhova originální formulace metody tzv. sociální introspekce a zdůraznění praktického rozměru lidské kognitivní aktivity [podrobně viz Janák 2006]. Ve svých úvahách o metodě sociálních věd vychází $\mathrm{z}$ novokantovského dělení věd a na základě Diltheyovy argumentace postuloval pro poznávací aktivitu v sociálních vědách také dimenzi hodnotící. 
Bláha si postupně uvědomoval problematičnost pozitivistického postulátu nepřekonatelnosti rozdílu mezi fakty a hodnotami, ačkoli jako profesor filosofie se zřetelem k sociologii jistě znal Humovu námitku, že ze jsoucího neplyne, co být má. Mostem k překlenutí rozdílu a jeho překonání je u Bláhy životní syntetizující aktivita subjektu, který je schopen organicky spojit poznání skutečnosti s hodnocením. Epistemologickým předpokladem takového Bláhova postoje je diltheyovské tvrzení, že na procesu poznání sociální skutečnosti se podílí životní zkušenost badatele, jeho „prožívání“ skutečnosti, které nutně zahrnuje také volní aspekty (chtění, ne/souhlas, ne/libost atp.). Jiným vyjádřením takového postoje je např. tvrzení, že poznání v sociálních vědách je spjato s velikostí osobního života, a tudíž na výsledném soudu participuje celá osobnost badatele. Poznání je tak do značné míry tvưrčím (životním) procesem, nikoli pasivním nahlížením holé fakticity.?

Z těchto základních postulátů Bláha vyvozuje, že hranice mezi poznáním a hodnocením není neprodyšnou zdí, ale do jisté míry oboustranně propustnou membránou. Faktuální znalost světa ovlivňuje hodnocení, volní aktivita má vliv na povahu faktuálních soudů. Bláhova subjektivistická metoda sociální introspekce je založena na přesvědčení, že adekvátní pochopení společenských jevů jde ruku v ruce s poznáními „zevnitřc“, s poznáním založeném na prožitku. Empirický výzkum pro něj tedy zahrnoval tvrdá fakta i mentální stavy. Tím jakoby setrvával v hlavní linii pozitivistického projektu - vycházet striktně ze zkušenosti, ale zároveň ho opustil, protože comtovský empirismus je spojen s odmítnutím introspektivních postupů, orientací na tvrdá fakta a odmítnutím mentálních fakt jako fakt.

Poměrně jasně a konzistentně drží Bláha demarkační linii nejen mezi fakty a fikcemi, ale i mezi fakty a hodnotami s tím, že fakt se může stát hodnotou díky emocionální a volní životní aktivitě subjektu. Fakta od hodnot lze tedy odlišit, ale nelze je zcela oddělit. I když Bláha vidí souvislosti mezi fakty a hodnotami, jeho pozice není tak radikální jako argumentace některých soudobých postanalytických badatelů, kteří hranici mezi fakty a hodnotami v podstatě stírají. Někteří badatelé z tohoto proudu [Rorty 2000; Putnam - Rorty 1997] formulují argumenty, „které mají ukázat, že to, co považujeme za fakty, není dáno předem, nezávisle na našem pohledu, ale je výsledkem jistého hodnocení skutečnosti. Z tohoto pohledu jsou fakty lidské konstrukty, jejichž pomocí pro sebe strukturujeme objektivní realitu. Je-li tomu tak, pak je spíše obtížné říci, v čem se odlišují od jiných lidských konstruktů, např́klad hodnot, pokud ovšem přijímáme představu, podle níž hodnoty samy jsou lidskými konstrukty [Svoboda - Kolář 1997: 45].“

Krajní konstruktivistické řešení postanalytických badatelů by Bláha velmi pravděpodobně nepřijal. V jistém protikladu k jejich postoji, že fakta závisí na hodnotách, by Bláha namítl, že také hodnoty plynou z fakt. Vztah hodnot a fakt je obousměrný: skutečnost je nám sice dána i skrze hodnocení, naše hodnocení však také vychází nebo může vycházet z objektivního poznání. To je silné tvrzení pro možnost angažované sociální vědy. Důležitý závěr pro nás zní, že Bláhovo pojetí empirie se neuzavírá hodnotám, i když hodnoty odlišuje od fakt a přijetí či odmítnutí jeho argumentů bude do značné míry záviset na vymezení oblasti empirie, které pro Bláhu zahrnuje i mentální stavy.

$7 \quad$ V tomto ohledu se Bláha stýká s novější postpozitivistickou pozicí Jeffrey C. Alexandera, který tvrdí, že „tvorba ,velké‘ sociální vědy je dar“, který, stejně jako schopnost tvorby velkého umění, spočívá na individuálních lidských schopnostech a variuje transhistoricky [Alexander 1987: 28]. 
Bláhovo pojetí se mi jeví udržitelné i plodnější než přístup krajního postanalytického konstruktivismu, který nivelizuje rozdíl různých typů konstruovanosti (vědecké, náboženské, commonsensuální atp.) a znemožňuje jiné než ad hoc pragmatické odlišení fakt a hodnot, čímž upadá do nebezpečí relativismu. Bláha naproti tomu trval na projektu vědecké etiky, respektive na doplnění vědy „novou“ filosofií - vycházející z výsledků věd a uchopující tyto výsledky za účelem zodpovězení otázek po smyslu a významu lidské aktivity. Ač problém rozdílu a přechodu mezi hodnotícími a faktuálními soudy neformuloval s takovou přesností, jak se o to pokouší badatelé v linii analytické filosofie [z českých např. již citovaní Svoboda - Kolář 1997], považuji jeho příspěvek v otázce vztahu poznání a hodnocení za jednu z nejzajímavějších a nejaktuálnějších částí jeho díla, která stojí za novou interpretaci a kritiku.

\section{Bláhova koncepce $v$ kontextu feministické epistemologie}

Třebaže není cílem tohoto textu detailně určit charakteristiky angažovaného výzkumu obecně, pro zhodnocení Bláhových epistemologických názorů je užitečné alespoň rámcové srovnání s epistemologickými názory soudobé angažované sociální vědy. Za paradigmatický př́klad takového typu výzkumu lze podle mého názoru považovat feministickou sociální vědu.

Feministickou sociologii, či odvozená rodová studia (gender studies) lze vzhledem k jejich genezi a původní i částečně přetrvávající alianci se sociálním hnutím feminismu označit za proud angažované sociologie. Původně sociálním hnutím inspirovaný angažovaný výzkumný proud si začal od 70. let budovat vlastní epistemologickou a metodologickou základnu jednak prostřednictvím kritiky stávajících kritérií vědecké racionality, objektivity a pravdy, která byla demaskována jako maskulinní, jednak skrze pozitivní budování vlastního teoreticko-metodologického stanoviska, jakými jsou např. texty Dorothy Smith [2002] publikované poprvé v 70. letech a Sandry Harding [1987b]). Dnes se feministicky orientovaný nebo inspirovaný výzkum silně diferencoval, takže vzhledem k množství autorů a přístupů, ale také pro jeho silnou interdisciplinaritu, není snadné zachytit jeho různorodost. Všechna generalizující tvrzení je proto třeba brát s určitou opatrností. Svoji pozornost jsem zaměřil především na texty, které se explicitně věnují obecným epistemologickým problémům feministické sociální vědy a autorky, které jsou považovány ve feministickém diskurzu za důležité. ${ }^{8}$

S oporou v této literatuře lze argumentovat, že minimálně část soudobého feministického výzkumu vykazuje podobné epistemologické postuláty jako sociologie Bláhova. Jedná se o kritiku ideálu nezaujatého pozorovatele a ideálu objektivity jako pohle-

8 Svoje tvrzení zakládám především na následujících textech: Etela Farkašová [2005a; 2005b] a Jan Matonoha [2005] věnovali své přehledové studie feministické epistemologii. Významným rozpracováním dialogického modelu objektivity v kontextu feministického bádání jsou texty Sandry Harding [1987a; 2004; 2006], včetně jejího pojetí tzv. silné objektivity (strong objectivity), kterou chápe spíše jako proces než jako stav mysli. Na „trhu“ feministických teorií jsou k dostání i varianty, které „situovanou objektivitu“ připisují skutečně spíše parciálním pozicím marginalizovaných jako pravdivější. Jde spíše o starší badatelské práce 70. let, např. Dorothy Smith. Studie Dagmar Lorenz-Meyer [2005] shrnuje a na příkladech ilustruje problematiku užití sebereflexivní metodologie ve feministickém výzkumu. Vedle sborníku Sandry Harding [1987] přináší některé důležité texty výbor Steve Jackson a Sue Scott [2002]. Užitečnou pomůckou pro orientaci ve feministickém diskursu je text vídeňské filosofky Herty Nagl-Docekal [2007]. 
du odnikud, která není zdaleka vlastní pouze feministické vědě, ale je společným jmenovatelem tzv. postmoderních koncepcí. Tato kritika ústí v takovou či onakou variantu dialogického a procesuálního pojetí objektivity (objektivní pravdy) a často upozorňuje na sociální situovanost vědění, která však není brána jako diskvalifikující.

Angažovaný postoj je chápán jako zdroj pravdivého poznání právě pro svou angažovanost, perspektivnost, situovanost. Jako by se ke slovu v nových reminiscencích a aktualizovaných souvislostech dostal klasický Mannheimův argument, který feminističtí autoři a autorky s oblibou ignorují, vyhlašujíce velký obrat ve filosofii vědy, že situovaná perspektiva nám umožňuje vidět charakteristiky z jiných úhlů neviděné. V klasické podobě tohoto argumentu byli např. komunisté schopni jako první odhalit „ideologičnost“ protivníkova buržoazního světového názoru právě proto, že byli komunisty [srv. Mannheim 1993: 171]. V nových kulisách jsou to ženy (nejlépe ještě „černé“ a s lesbickou orientací), které jsou s to odhalit androcentrismus západní kultury včetně vědy $\mathrm{s}$ jejím neviditelným, ale o to citelnějším předivem mocenské dominance [ke kritice „racionálního muže vědy"viz Jackson - Scott 2002].

Epistemologické názory obhajující legitimitu a pravdivost sociálně situovaného vědění označuji jako stanoviskové epistemologie. V rámci současného do široka rozlitého proudu epistemologické sebereflexe feministicky orientovaného výzkumu jsou klíčovými pojmy „situovanost“ a „pozicionalita“, používané v kritické distanci k tradiční představě tzv. autonomního rozumu, nesituovaného a nezaujatého pozorovatele [Farkašová 2005b: 64-65]. Pojem „stanovisková epistemologie“, který používám, je odlišný od tzv. „teorie stanoviska“, jež je ve feministickém diskursu etablovaným označením teorií, které považují určitou marginalizovanou či potlačenou individuální nebo kolektivní sociální pozici za epistemologicky privilegovanou [srv. Lorenz-Meyer 2005]. Oproti tomu jiné „stanoviskové epistemologie“ (zejména postmoderně orientované) odmítají epistemologickou privilegovanost jedné situovanosti a zdůrazňují nestabilitu situovanosti, jiné př́istupy zase zaměřují pozornost na situovanost koncepce objektivity [Harding 2004]. Protože epistemologické úvahy věnované situovanosti a pozicionalitě již dávno překonaly čistě kritickou orientaci na mocenské rodové nerovnosti, označení stanovisková epistemologie zastřešuje i epistemologické názory teorie stanoviska, ale zároveň zahrnuje i další a někdy značně odlišné koncepce situovaného poznání.

V souvislostech výzkumu Bláhovy koncepce je důležité si uvědomit, na co poukázala Etel Farkašová, že „stanovisková koncepce se stává bází nejen výzkumných projektů, ale i politických strategií - spojujíc tak dvě sféry, na které se tradičně nahlíželo jako na separované, ba dokonce neslučitelné“ [Farkašová 2005a: 402]. Jde o velmi aktuální pokus epistemologicky fundovat politickou aktivitu, nebo alespoň propojit vědu s politikou, pokud vědu spojujeme s objektivním poznáváním a politiku se zájmy, chtěním a mocí.

Jan Matonoha [2005: 34-35] shrnuje ve svém textu o feministické epistemologii a kritice vědeckého diskursu základní body, na něž feministický př́istup k vědě klade důraz. Jedná se o situovanost vědění, ztrátu privilegované metapozice vědoucího subjektu a sebereflexivitu badatele. Feministický př́stup tematizuje propojení vědění a moci a poukazuje na to, že objektivita není vlastnost nezaujatého subjektu, ale v poslední instanci výsledek konsenzu interpretativní (vědecké) komunity. Jako kritikové stávajícího vědeckého diskursu usilují feminističtí badatelé o „celkovou proměnu vědeckého paradigmatu, 
o inkorporování pluralitního spektra jednotlivých, alternativních a vědomě parciálních, situovaných způsobů uvažování a vypovídání o světě kolem nás [Matonoha 2005: 35].“

Díky tomu se také feministická metodologie často orientuje na problém uchopení vlastní sociální zkušenosti badatele, tj. na využití sebereflexe vlastní sociální zkušenosti (která není v principu nikdy neutrální) při výzkumu. Jedním z textů, který podává zprávu o šíri sebereflexivních přístupů v sociálních vědách je stat Lorenz-Meyer [2005]. Sebereflexivní metodologie realizovaná introspektivním postupem má však v současných koncepcích poněkud odlišné směřování než u Bláhy. Základní podobnost je v tom, že individuální proživání určité sociální pozice je zdrojem sociologického poznání. Rozdíl spočívá v epistemologickém statusu takového poznání. Zatímco novodobé stanoviskové epistemologie většinou tematizují skupinovou nebo individuální parcialitu a očekávají, že objektivní poznání „vypadne“ až z diskuse a konfrontace rozličných stanovisek, Bláhovou snahou bylo tuto parciálnost překročit a přechod k objektivnímu poznání učinit již na úrovni subjektu - prací s objektivními vědeckými pojmy a školeností ve vědeckém myšlení.

Bláha tvrdí, že jsme schopni říci, co je rodina, strana, národ, společnost, protože je individuálně prožíváme, novodobá epistemologie naproti tomu říká, že nevíme, co je rodina, strana, národ, společnost jako takové právě proto, že je prožíváme jako členové určité parciální rodiny, aktivisté jisté strany, příslušníci konkrétního národa. Zatímco u Bláhy je vůdčí a dobově podmíněnou ideou syntéza uplatněná i na individuální poznání, soudobé epistemologie neméně dobově zdůrazňují pluralitu a heterogenitu v intencích vize pluralitního sociálního světa. Některé přístupy (např. koncepce Elspeth Probyn) sice tematizují dialogický model již na úrovni subjektu, nicméně chápou subjekt spíše jako průsečík jinak parciálních stanovisek [srv. Lorenz-Meyer 2005: 80].

Klíčovým bodem zmiňovaných epistemologických úvah a styčnou plochou s úvahami Bláhovými je, že hodnocení je pojato jako součást poznávací aktivity badatele. ${ }^{9}$ Z tohoto spojení může angažovaný výzkum čerpat určitou legitimitu. Tato legitimita však neplyne $\mathrm{z}$ ušlechtilosti cílů, $\mathrm{k}$ nimž sociologická angažovanost může směřovat, ale z ontologických a epistemologických východisek koncepce (pojetí pravdivosti, empirie, fakticity, pojmu poznání, základních pojmů obecné sociologické teorie apod.), které ji „uschopňují“ k sociální praktičnosti více než východiska jiná.

\section{Závěr}

V předchozím textu jsem se pokusil naznačit body, v nichž sociologie Inocence A. Bláhy rezonuje s tou dnešní. Možnost aktualizace Bláhovy sociologie spatřuji v oblasti jeho sociologické angažovanosti, kterou jsem zasadil do kontextu soudobých diskusí o veřejné sociologii a feministických epistemologických názorech. Za tímto účelem bylo nutné věnovat určitý prostor Bláhově obecné sociologické teorii.

Srovnání Bláhovy sociologické angažovanosti a některých dalších způsobů praktikované veřejné sociologie ukázalo, že normativismus není nutným atributem veřejné

9 Vzhledem k rozsahu textu alespoň v poznámce pod čarou uvedme, že zahrnutí hodnotícího prvku do aktu vědeckého poznání není v současné sociální vědě zdaleka omezené jen na feministický výzkum. Z oblasti filosofie jmenujme např. fenomenologa Rogera Barbarase [2005], z fenomenologické sociologie Lestera Embreeho [2003] nebo jednoho z nejznámnějších novodobých sociologů Pierra Bourdieu [2003] 
sociologie a pokud je v sociologické analýze př́tomen, může nabývat různé intenzity. Proto je vhodné od sebe odlišit veřejnou a angažovanou sociologii. Zatímco veřejná sociologie poukazuje pouze na vstup sociologického vědění do veřejného prostoru, angažovaná sociologie s sebou nese vždy určitý normativismus, protože angažovat se lze vždy jen za něco nebo někoho.

Angažovaná sociální věda zpochybňuje jasnou oddělitelnost fakt a hodnot a pokouší se o propojení faktuálních soudů s hodnotovými. To se ukázalo alespoň při srovnání těch několika uvedených př́kkladů, a proto je tento závěr vhodné brát jako hypotézu žádající si další precizaci. U Bláhy se toto propojení děje na základě diltheyovského př́stupu. Ve feministických epistemologiích, jež tematizují sociální situovanost vědění (v textu je označuji jako stanoviskové epistemologie), se tak děje v procesu vztahování vlastních poznávacích soudů k lokalizaci (sociální, myšlenkové, prostorové, relační vzhledem k objektu zkoumání atd.) subjektu vědění - tj. badatele. Důležitým implicitním důsledkem spojení poznání a hodnocení je pro angažovanou vědu vzájemnost obou kognitivních sfér. Hodnocení ovlivňuje poznání a poznání ovlivňuje hodnocení. I když vazba hodnocení a poznání (chtění a faktů) oslabuje představu o neomylnosti či nezaujatosti vědeckého poznání, na druhou stranu oslabuje také představu o tom, že při vyslovování hodnotících soudů se pohybujeme ve sféře naprosté libovůle či iracionální intuice, a podporuje myšlenku, že i hodnotově zatížený diskurs je možný jako racionální. Je ovšem třeba vyjasnit povahu vazby hodnotových soudů na faktuální.

Zdá se, že tato vazba, stejně jako nejasnost přechodů mezi fakty a hodnotami, mezi teoretickými a deskriptivními soudy, je daleko více uvědomována v linii hermeneutického zkoumání než v linii kvantitativního výzkumu, tam, kde pojem empirie zahrnuje tzv. tvrdá i mentální fakta. Bláha přechod mezi teoretickými, faktuálními a hodnotícími soudy byl schopen realizovat až po opuštění pozitivistických východisek a přijmutí argumentace filosofie života, ústící v subjektivistickou metodologii. Feministické epistemologie zohledňující vlastní sociální zkušenost jako zdroj vědeckého poznání také pracují více s kultivací porozumění sociální zkušenosti než s její kvantifikací.

Uvedené závěry je třeba brát jako hypotézy, vyžadující další zpřesnění a vymezení hranic platnosti. V jubilejně motivovaném textu snad mohou posloužit jako př́íklad sociologicky smysluplného využití zkoumání (sociologické) minulosti k porozumění naší (nejen sociologické) současnosti. 


\section{Literatura}

Alexander, Jeffrey. [1987]. The Centrality of Classics. In. Gidens, Anthony - Turner, Jonathan H. (eds.). Social Theory Today. Standford: Stanford University Press. s. 11-57.

Balon, Jan. [2009] Projekt veřejné sociologie: cesta ven z krize oborové sociologie? Teorie vědy 47 (2009), číslo 4, s. 73-99.

Balon, Jan. [2009] Ambivalentní odkaz Millsovy Sociologické imaginace. Sociologický časopis 45 (2009), číslo 5, s. 1055-1073.

Barbaras, Roger. [2005]. Touha a odstup. Praha: OIKOMENH.

Bauman, Zygmunt. [2002]. Úvahy o postmoderní době. Praha: SLON

Beck, Ulrich. [2005]. How not to Become a Museum Piece. British Journal of Sociology 56 (September 2005), No. 3, s. 335-343.

Bláha, Inocenc A. [1913-1914]. K psychologii malého města. Lidové noviny 21 (1913), číslo 199, s. 1-2; číslo 213 (1913), s. 1-2; číslo 223 (1913), s. 1-2; číslo 254 (1913), s. 1-2; číslo 268 (1913), s. 1-2; číslo 274 (1913), s. 1-2; Lidové noviny 22 (1914), číslo 30, s. 1-2; číslo 35 (1914), s. 1-2; číslo 41 (1914), s. 1-2; číslo 65 (1914), s. 1; číslo 72 (1914), s. 1-2.

Bláha, Inocenc A. [1914]. Město. Sociologická studie. Praha: Melantrich.

Bláha, Inocenc A. [1919]. Od osvobození mravního k osvobození politickému. Nové Město na Moravě: Vydavatelské družstvo.

Bláha, Inocenc A. [1921a]. Mravní výchova se stanoviska sociologického. Nové město na Moravě: Vydavatelské družstvo.

Bláha, Inocenc A. [1921b]. Problém hodnocení. Naše doba 28 (1921), s. 658-664, s. 738-745.

Bláha, Inocenc A. [1922a]. Filosofie mravnosti. Brno: Píša.

Bláha, Inocenc A. [1922b]. K psychologii doby. Kniha studiú. Praha: Bursík a Kohout.

Bláha, Inocenc A. [1925]. Sociologie sedláka a dělníka. Př́spěvek k sociologii společenských vrstev. Praha: Orbis.

Bláha, Inocenc A. [1926]. Zásady pokrokové politiky. Brno.

Bláha, Inocenc A. [1927]. Sociologie dětství. Praha, Brno: Ústřední spolek jednot učitelských na Moravě, Dědictví Komenského v Praze.

Bláha, Inocenc A. [1929]. O laický základ mravní výchovy. Kritické poznámky k Rádlově brožure Revise pokrokových ideálio v národní škole. Brno: Ústřední spolek jednot učitelských na Moravě.

Bláha, Inocenc A. [1930a]. Masaryk a věda. Brno: Rolnická tiskárna.

Bláha, Inocenc A. [1937]. Sociologie inteligence. Praha: Orbis.

Bláha, Inocenc A. [1940]. Vědecká morálka a mravní výchova. Praha: Život a práce.

Bláha, Inocenc A. [1946]. Kultura a politika. Brno: Zemská osvětová rada.

Bláha, Inocenc A. [1947a]. Jak se dívat sociologicky na život. Brno: Masarykova sociologická společnost.

Bláha, Inocenc A. [1947b]. Dnešní krize rodinného života. Praha: Nakladatelství E. Fastra.

Bláha, Inocenc A. [1968]. Sociologie. Praha: Academia.

Bourdieu, Pierre [2003]. Zúčastněná objektivace: Huxleyho přednáška. Biograf č. 30 (březen 2003), s. 3-17.

Burawoy, Michel. et al. [2004]. Public Sociologies: a Symposium from Boston College. Social Problems 51 (February 2004), No. 1, s. 103-130.

Burawoy, Michael [2005a]. 2004 American Sociological Association Presidential address: For public sociology. The British Journal of Sociology 56 (June 2005), No. 2, s. 259-292.

Burawoy, Michael. [2005b]. Response: Public Sociology: Populist Fad or Path to Renewal? The British Journal of Sociology 56 (June 2005), No. 2, s. 417-432.

Durkheim, Émile. [1926]. Pravidla sociologické metody. Praha: Orbis.

Durkheim, Émile. [2004]. Společenská dèlba práce. Brno: CDK.

Embree, Lester. [2003]. Konstituce základní kultury. In. Blecha, I. (ed.) 2003. Fenomenologie $v$ pohybu. Olomouc: Olomouc, s. 35-44. 
Engliš, Karel. [1930]. Teleologie jako forma vědeckého poznání. Praha: F. Topič.

Ericson, Richard. [2005]. Public Sociology. British Journal of Sociology 56 (September 2005) No. 3, s. 365-372.

Farkašová, Etela. [2005a]. Može byt rozum „emocionálny“ a objektivita „perspektívna? (K problematike poznania vo feministických epistemológiach). “In. Linková, Marcela - Červinková Alice. (eds.). Myšlení hranic: genderové pohledy na racionalitu, objektivitu a vědoucí subjekt. Praha: Sociologický ústav AV ČR, s. 57-74.

Farkašová, Etela. [2005b]. Stanovisko ako epistemologická/metodologická stratégia? (Diskuse v súčasnej feministickej filozofii). Filozofia 60 (2005), číslo 6, s. 399-412.

Fischer, Josef L. [1933a]. Krise demokracie. kniha I.: Svoboda. Brno: Index a Pokrokový obzor.

Fischer, Josef L. [1933b]. Krise demokracie. kniha II.: Řád. Brno: Index a Pokrokový obzor.

Giddens, Anthony. [1994]. New Rules of Sociological Method: a Positive Critique of Interpretative Sociologies. Stanford: Stanford University Press, 2. vydání s Novým úvodem (první vydání London: Hutchinson, 1976).

Hall, John A. [2005]. A Guarded Welcome. British Journal of Sociology 56 (September 2005), No. 3, s. 379-381.

Harding, Sandra. (ed). [1987a]. Feminism and Methodology. Indiana University Press.

Harding, Sandra. [1987b]. Introduction: Is There a Feminist Method? In. Harding, S. (ed.). Feminism and Methodology. Bloomington: Indiana University Press, 1-14.

Harding, Sandra. [2004]. The Feminist Standpoint Theory Reader. Intellectual and Political Controversies. New York - London: Routledge.

Harding, Sandra. [2006]. Science and Social Inequality. Feminist and Postcolonial Issues. Urbana, Chicago: University of Illinois press.

Jackson, Steve - Scott, Sue. (eds.) [2002]. Gender. A Sociological Reader. London: Routledge.

Janák, Dušan. [2006]. Sociální introspekce I. A. Bláhy a Wittgensteinův argument proti soukromému jazyku. Poznámky k introspektivnímu př́stupu v sociálních vědách. Sociologický časopis 42 (2006), číslo 4, s. 761-782.

Keller, Jan. [1992a]. Úvod do sociologie. Praha: SLON.

Klofáč Jaroslav - Tlustý Vojtěch. [1965]. Soudobá sociologie I. Praha: Nakladatelství politické literatury.

Kusá, Zuzana. [2006]. Verejná sociológia a sociologický étos. (prednáška na výročnej konferencii Českej Masarykovej sociologickej spoločnosti Čím žije česká sociologie FSS MU Brno 19.20. 1. 2006). [online], dostupné na stránkách Sociologického ústavu SAV, < http://members. chello.sk/zuzakusa/public\%20sociology.html > [20. 1. 2010]

Light, Donald W. [2005]. Contributing to Scholarship and Theory through Public Sociology. Social Forces 83 (June 2005), No. 4, s. 1647-1654.

Lorenz-Meyer, Dagmar. [2005]. O politice lokace: Strategie používané ve feministické epistemologii a jejich význam pro výzkum prováděný z feministické perspektivy. In. Linková Marcela - Červinková, Alice. (eds.). Myšlení hranic: genderové pohledy na racionalitu, objektivitu a vědoucí subjekt. Praha: Sociologický ústav AV ČR, s. 75-96.

Luhmann, Niklas. [2006]. Sociální systémy. Nárys obecné teorie. Brno: CDK.

Matonoha, Jan. [2005]. Ženy a věda: feministické epistemologie a kritika vědeckého diskursu. In. Linková, Marcela - Červinková, Alice. (eds.). Myšlení hranic: genderové pohledy na racionalitu, objektivitu a vědoucí subjekt. Praha: Sociologický ústav AV ČR, s. 25-38.

Merton, Robert K. [1965]. Social Theory and Social Structure. New York: Free Press.

Nagl-Docekal, Herta. [2007]. Feministická filosofie: výsledky, problémy, perspektivy. Praha: SLON. Parsons, Talcott. [1964]. The Social System. New York: Free Press.

Putnam, Hillary - Rorty, Richard. [1997]. Co po metafyzice? Bratislava: Archa.

Reich, Robert. [2002]. Dílo národů. Př́prava na kapitalismus 21. století. Praha: Prostor.

Rorty, Richard. [2000]. Filozofia a zrkadlo prírody. Bratislava: Kalligram.

Sedlák, Jiří. [2000]. Co je z Bláhy stále živého? Rozhovor s I. Gadourkem, M. Gregorem, V. Kadlecem, M. Kubíčkovou, P. Páclem, M. Petruskem a J. Sedlákem. Univerzitní noviny 7 (2000), č. 5, s. 67-71. 
Smith, Dorothy. [2002]. Women's Perspective as a Radical Critique of Sociology. In. Jackson, Scott - Scott, Sue. (eds.). Gender. A Sociological Reader. London: Routledge, s. 55-67.

Svoboda Vladimír - Kolář Petr. [1997]. Logika a etika: úvod do metaetiky. Praha: Filosofia.

Vaughan, Diane. [2005]. On the Relevance of Ethnography for the Production of Public Sociology and Policy. British Journal of Sociology 56 (September 2005), No. 3, s. 411-416.

Zouhar, Jan - Pavlincová, Helena - Gabriel, Jiř́. [2005]. Demokracie je diskuse... Česká filosofie 1918-1945. Olomouc: Olomouc.

Dušan Janák (1979) vystudoval sociologii na Fakultě sociálních studií Masarykovy univerzity v Brně, kde získal také doktorát. V současnosti působí na Slezské univerzitě v Opavě. Zabývá se dějinami sociálního myšlení, sociální filosofií a filosofií sociálních věd. $V$ těchto oblastech publikoval několik statí $v$ odborných časopisech. Je autorem knihy Hodnoty a hodnocení v sociologii Inocence Arnošta Bláhy. Studie z dějin klasické české sociologie (2009). 